\title{
RELIGIJSKI STIL (ANALIZA FUNKCIONALNOG STILA)
}

SAŽETAK

Ciljevi i zadaci ovog rada manifestiraju se u težnji da se na osnovu analiziranih tekstova, hutbi/vazova i homilija doprinese tvrdnji da je religijski stil, zaseban funkcionalni stil, sa svojim specifičnim osobinama i funkcijama. Od svih religijskih žanrova i vrsta, odabrane su baš religijske retoričke vrste, hutbe/vazovi i homilije, zato što oni najviše "iskaču" iz unaprijed zadanih šablona religijskog stila $i$ dozvoljavaju hatibu/homiletu najviše slobode pri izražavanju individualnog stila. Upravo, uzimajući "najslobodniju" vrstu unutar religijskog funkcionalnog stila, nastojalo se ukazati, da bez obzira na utjecaj individualnog stila i gubljenja nekih karakterističnih osobina religijskog stila, hutbe/vazovi $i$ homilije ipak zadržavaju i pokazuju najkarakterističnije osobine religijskog stila, što dokazuje opravdanost izdvajanja ovog stila, kao samostalnog funkcionalnog stila.

Ključne riječi: stil, diskurs, registar, sociolingvistika, funkcionalna diferencijacija jezika, funkcionalna stilistika, religijski funkcionalni stil, tekstualna stilistika, jake pozicije teksta, hutbevazovi-homilije, božanska datost jezika, leksika, persausivnost, umjetnička vrijednost

\section{UVOD}

$\mathrm{U}$ tradicionalnoj, funkcionalnoj podjeli jezika, religijski stil dugo vremena nije bio priznat kao samostalan stil, zanemarivan je i naprosto pripajan književno-umjetničkom stilu. Ovakav pogled na funkcionalnu diferencijaciju jezika moramo posmatrati ograničenim i diskriminirajućim, jer ne postoje nikakvi argumenti ("osim ideoloških"), na osnovu kojih se religijski stil ne bi mogao izdvojiti, kao samostalan funkcionalni stil. Naprotiv, ovaj stil je star koliko i sam čovjek, rastao je i razvijao se sa njim, te bismo slobodno mogli tvrditi, ako imamo u vidu historiju ljudske pismenosti, da je ovaj stil sa svojim mnogobrojnim žanrovima i vrstama utjecao i na samu funkcionalnu diferencijaciju jezika. Ovako velik značaj religijskog 
stila uočila je Mečkovskaja, poznata ruska lingvistica, koja kaže: ,Sakralni stil obuhvata sferu usmene $i$ pismene religijske komunikacije, tako da je žanrovski veoma raznorodan-počev od svetih knjiga različitih religija pa do jezika i stila izvođenja religijskih obreda, molitvi, obraćanja vjerskih službenika vjernicima i slično. Upravo ova stroga diferencijacija žanrova, tačnije svojevrsna hijerarhija sakralnih tekstova, znatno je utjecala na funkcionalno raslojavanje jezika uopće, kao i na uočavanje specifičnih stilskih svojstava različitih tipova upotrebe jezika uopće.

Dakle, mi ne smijemo zaboraviti da je prvo čovjekovo interesovanje za jezik, bilo interesovanje za jezik magije i kulta, te da su različite svete knjige i tekstovi imali neopisivu ulogu u razvoju pismenosti svih naroda svijeta. Upravo, ta sakralizacija pisma dovela je do toga da se slovo i tekst postave u centar intelektualnih interesovanja društva, tako da su se svi najveći umovi u historiji čovječanstva, ako ništa, bar dodirnuli pitanja pisma, jezika i stila. Iako sve svete knjige i tekstove možemo posmatrati i kao književnoumjetnička djela, mi ne smijemo zanemariti neospornu činjenicu da umjetnička funkcija nije njihova primarna funkcija. Na osnovu njihove nesumnjive umjetničke vrijednosti, mi svakako tekstove, unutar religijskog stila, možemo proučavati ne samo kao isključivo religijske tekstove, nego i sa književno-umjetničkog aspekta, ali ta činjenica nimalo ne opravdava svrstavanje religijskog stila u književno-umjetnički stil.

\section{FUNKCIONALNO RASLOJAVANJE JEZIKA (JEZIČKE FUNKCIONALNE VARIJACIJE)}

Još u vrijeme antike, u sklopu retorike, uočeno je raslojavanje jezika, pa su se analogno tome razlikovale tri vrste stila: prosti stil ili niski stil (genus subtile, évaqyéza), kojim se govorilo o malim, neznatnim stvarima i koji se upotrebljavao za tumačenje i

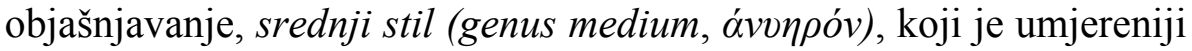
i prati izlaganje stvari koje zaokupljuju duh, ali ga ne uzbuđuju i uzvišeni ili visoki stil (genus grande atque robustum, óvvqqóv), koji se koristio za izražavanje značajnih $\mathrm{i}$ velikih misli, te služio za propovijedanje jakih osjećaja i velikih i neobičnih događaja. Pored

\footnotetext{
${ }^{1}$ M. Katnić-Bakaršić, Stilistika, Ljiljan, Sarajevo, 2001., str. 70.
} 
ovakve podjele postojala je i ona koja razlikuje tri vrste diskursa (govora, besjede): sudski (genus iudicale), politički (genus deliberativum) i svečani (genus demonstrativum). Veliki filozof Aristotel također je uočio funkcionalno raslojavanje jezika i kaže: „,Ne bi trebalo zaboraviti da svakom rodu besede odgovara poseban stil. Nije isti stil u pisanoj $i$ parničarskoj besedi, niti u skupštinskim $i$ sudskim besedama." ${ }^{2}$ Kvintilijan, jedan od najpoznatijih učitelja retorike, jasno ističe da se govorništvo ne može ograničiti na samo tri stila. Protivi se ovako oštroj podjeli i kaže da stil dopušta bezbroj varijanti sa mnogim zajedničkim svojstvima, a često suptilnim razlikama. Dakle, on svojim suprotstavljanjem, vještačkoj podjeli na tri stila, prihvata navedeno Aristotelovo učenje o jedinstvu stila, te njegovim raznim varijacijama. Kvintilijan definira i pojam stila pa kaže: „Materija stila, u širem smislu riječi, jesu riječi uzete pojedinačno i riječi u jezičnom sklopu. Prema tome ljepota stila ovisi u prvom redu o izboru pojedinih riječi, njihovom pravilnom poretku unutar rečenice $i$ o stilskim ukrasima koji proizlaze iz upotrebe stilskih figura. "

U tradicionalnoj normativnoj lingvistici sve do pojave strukturalizma i teorije funkcionalnih stilova dominiralo je mišljenje da stil predstavlja jezik nekog književnika ili grupe književnika što nam sa današnjeg stanovišta naravno izgleda kao puki apsurd. Po najopćenitijoj definiciji stil je način na koji se nešto radi, odnosno forma pomoću koje se realiziraju različiti sadržaji. Analogno tome, stil u jeziku je način izražavanja određenog sadržaja ili još konkretnije on predstavlja različite načine (forme) izražavanja istog sadržaja. Međutim, u suvremenoj poststrukturalističkoj lingvistici, stil ne može biti samo forma sadržaja, jer između stila i značenja postoji ekvivalencija (istoznačnost). Promjenom same forme, nužno dolazi i do promjene sadržaja. Ovakva teorija proizlazi iz mišljenja da pravih sinonima ustvari i nema, te da svaki sinonim nužno mora unijeti i određene, veće ili manje, nijanse značenjskih promjena. Iz toga proizlazi da je pitanje sinonimije centralno pitanje stilistike. Prvi koji je ukazao na ovu problematiku bio je C. Bally, poznati lingvist i Saussureov nasljednik na katedri opće lingvistike u Ženevi, svojom

\footnotetext{
${ }^{2}$ M. Katnić-Bakaršić, Stilistika, Ljiljan, Sarajevo, 2001., str. 55.

${ }^{3}$ M. F. Kvintilijan, Obrazovanje govornika, Veselin Masleša, Sarajevo, 1985., str. 24.
} 
teorijom o afektivnim jezičkim sredstvima iz 1909. god., koja je nastala kao reakcija na Foslerovu i Spitzerovu stilističku školu u kojoj se književni jezik poistovjećivao sa jezikom umjetničke književnosti. Bally je prvi lingvist koji je, unoseći u jezičku analizu sociološke i psihološke kriterije, ukazao na potrebu proučavanja funkcionalnih stilova. Neki autori, kao npr. R. Simić i J. Jovanović, kao prvog začetnika ideje o funkcionalno-stilističkom posmatranju i proučavanju jezika, u suvremenom smislu ovog termina, smatraju A. A. Potebnju. Međutim, najznačajniji za funkcionalnu stilistiku su pripadnici praškog lingvističkog serkla, koji su 1929. god., u prvom broju svoje publikacije, objavili svoj lingvistički program, poznate Teze (Travaux du Cercle Lingistique du Prahue, I, 1929.). Pražani jezik shvataju kao sistem izražajnih sredstava koji služe sporazumijevanju. Oni odbijaju dotadašnje shvatanje da se jezik proučava kao zatvoreni, imanentni sistem, jer on to ustvari i nije i zato Pražani ističu da je funkcija jezika kao djelatnost jednog funkcionalno organiziranog sistema upravo osnovni problem stilističkog izučavanja. To su i naveli u svojim Tezama ( Travaux du Cercle Linguistique de Prague, I, 1929.): „Zato treba proučavati konkretnu funkciju, konkretnih jezičkih iskaza (šta se obavještava, kako, kome, u kojoj prilici). Jezik je realnost čiji je tip uslovljen spoljašnjim (nelingvističkim) momentima, socijalnom sredinom, auditorijem kojem se saopštava, tematikom koja se iznosi. Stoga je neophodno razlikovati i teorijski i praktično jezik kulture uopšte od jezika "lijepe" književnosti, jezik nauke od jezika novina, jezik ulice od jezika kancelarije itd. "“ Upravo zahvaljujući Pražanima i ovakvom pogledu na funkcionalnu ulogu jezika razvija se funkcionalna stilistika, koja postaje dominirajući lingvistički pravac od druge polovine XX stoljeća, tačnije od 1959. god. kada dolazi do značajnih rasprava i diskusija u najznačajnijim stilističkim školama toga vremena (romanskoj, ruskoj i čehoslovačkoj). O značaju Pražana V. M. Minović u svom djelu Uvod u nauku o jeziku kaže: "Razmatrajući stil u širokom komunikacijskom prostoru konstituisali su glavna načela funkcionalne stilistike. Naime, zastupali su gledište da jezik treba proučavati u svim vidovima, primarno sa sinhroničkog, ali i sa dijahroničkog aspekta. Znači svestrano. Razradili su učenje o jeziku kao sistemu koji ima svoje funkcije s obzirom na cilj upotrebe. Ustanovili su da izbor jezičkih sredstava zavisi od ciljeva iskaza,

\footnotetext{
${ }^{4}$ M . Ivić, Pravci u ligvistici, Državna založba Slovenija, Ljubljana, 1970. str. 126.
} 
odnosno da funkcionisanje jezičkog sistema stoji u direktnoj vezi sa različitim ciljevima iskaza. ${ }^{\prime 5}$ Tošović navodi tri osnovna pristupa determinaciji pojma stila: opšteumjetnički, književni i lingvistički:"Kao naučni pojam funkcionalni stil je apstraktni makrosistem tipičnih elemenata izlučenih iz sličnih ili podudarnih tekstova (iskaza). U međuprostoru između apstraktnog $i$ konkretnog postoje međusistemi, podsistemi i sl., koji predstavljaju niži sistem uopštavanja. Funkcionalni stil je prema tome naučna apstrakcija do koje se dolazi induktivnim putem. ${ }^{\prime 6}$ Dakle, upravo zavisno od toga s kakvog se aspekta gleda na stil, daju se najrazličitija tumačenja i definicije.

U samom lingvističkom pristupu pojmu stil također vlada pravo šarenilo koje je rezultat različitih lingvističkih škola, pravaca, sredina i individualnih stavova. Neki autori, kao npr. D. Crystal, smatraju da se stil može posmatrati samo na nivou idiostila, tj. samo na individualnom nivou, jer stil za njih predstavlja skup jezičkih karakteristika po kojima se pojedinci razlikuju, tako da se on može izjednačiti sa bazama ličnog lingvističkog identiteta. U modernoj ruskoj lingvistici, kao posebno značajna definicija, bi se mogla uzeti ona koju je dao Vinogradov, a koja glasi: "Stil jezika je semiotički zatvoren, ekspresivno ograničen svrsishodno organizovan sistem sredstava za izražavanje, koji odgovaraju ovom ili onom žanru književnosti ili pismenosti, ovoj ili onoj sferi društvene aktivnosti, ovome ili onome karakteru jezičkih odnosa između raznih članova ili slojeva društva. ${ }^{\prime 7}$

Ova definicija je djelomično funkcionalno orijentirana i na pola je puta da definiše stil kao funkcionalno-stilsku kategoriju. U češkoj lingvistici jednako značajna definicija je ona koju je dao Havranek (kojeg B. Tošović smatra ocem funkcionalne stilistike), a koja glasi: "Stil je način upotrebe(izbor)jezičkih sredstava u datim jezičkim iskazima u zavisnosti od konkretnog cilja, forme, situacije, tako $i$ u zavisnosti od individualne orijentacije govornog lica, odnosno

\footnotetext{
${ }^{5}$ H. Muratagić-Tuna, Nešto o naučnom funkcionalnom stilu, Časopis "Književni jezik", 21/2

${ }^{6}$ B. Tošović, Funkcionalni stilovi, Institut für Slawistik der Karl-Franzens-Uniwersität Graz, Grac, 2002, str. 11.

${ }^{7}$ B. Ibid., str. 40 .
} 
pisca. ${ }^{\prime \prime} 8$ Po ovoj definiciji, dvije su osnove stila, konkretna društvena funkcija i individualna organizacija jezičkih sredstava. Pored ove Havranekove definicije, kao naročito značajna mogla bi se izdvojiti i ona koju je dao Mistrik, a koja glasi: "Jezički stil je način izbora, organizacije $i$ upotrebe jezičkih sredstava u odnosu na tematske $i$ ostale vanjezičke elemente iskaza. Suprotno tome, jezik iskaza je repertoar na isti način upotrebljenih jezičkih sredstava bez obzira na njihov odnos prema nejezičkim elementima iskaza." ${ }^{\prime 9}$ H. MuratagićTuna navodi da se po ocjeni najvećeg broja lingvista najboljom definicijom smatra ona koju je dala M. N. Kožina, a koja glasi: "Funkcionalni stil je osoben karakter govora ove ili one socijalne vrste koja odgovara određenoj oblasti društvene aktivnosti $i$ korelativnom obliku svijesti, koju stvaraju osobenosti funkcionisanja jezičkih sredstava u toj oblasti $i$ specifična govorna organizacija, što joj daje stilističku obojenost (makroobojenost)." ${ }^{10}$ Upravo zbog ovakvog šarenila u determinaciji pojma stila, koje bi se možda najbolje moglo okarakterisati izjavom Umberta Eca da termin stil govori ili previše ili premalo, u lingvistici se javljaju pojmovi registar i diskurs, koji su po nekima lingvistima, a posebno anglosaksonskim, pogodniji za lingvistički konkretniju upotrebu. Pojam registra preuzet je iz sociolingvistike. O tome Flower kaže: "Sam termin registar preuzet je iz sociolingvistike, a trebalo je da zamjeni upotrebu pojma stil, koji je smatran suviše širokim, višeznačnim, nedovoljno preciznim. ${ }^{\prime 11}$ Da bismo shvatili sociolingvističko posmatranje jezičkih varijeteta, svakako je nužno odrediti sam predmet sociolingvistike. Predmet proučavanja sociolingvistike, na vrlo lijep način, određuje definicija koju je dao D. W. Halwachs, koji kaže: "Sociolingvistika je - kao što joj samo ime govori-međustrukovna disciplina, $i$ sadržajno $i$ metodički između sociologije $i$ lingvistike: sadržajno jer se jezik primarno smatra socijalnim fenomenom, odnosno sociokulturnim odrazom, a metodički na temelju visokog vrednovanja empirije, odnosno činjenice da je jezična stvarnost određene zajednice

\footnotetext{
${ }^{8}$ B. Tošović, Funkcionalni stilovi, Institut für Slawistik der Karl-Franzens-Uniwersität Graz, Grac, 2002, str. 44.

${ }^{9}$ Ibid., str. 46.

${ }^{10}$ H. Muratagić- Tuna, Nešto o naučnom funkcionalnom stilu, Časopis "Književni jezik", 21/2

${ }^{11}$ M. Katnić-Bakaršić, Stilistika, Ljiljan, Sarajevo, 2001., str. 35.
} 
govornika temelj svakog sociolingvističkog istraživanja." ${ }^{12}$ Pojam diskursa, sociolingvistika funkcionalno gledano definira kao jedinicu višeg reda, govorni čin, govorni događaj. M. Radovanović u svom djelu Sociolingvistika kaže:"Gledano funkcionalno, a ne sa stanovišta njihovog formalnog gramatičkog statusa, $i$ lekseme $i$ jedinice sa sintaksičko-semantičkog nivoa mogu se na nivou teksta tretirati i kao jedinice višeg reda, dakle kao govorni čin, govorni događaj, tekst ili diskurs... To su, zapravo, svojevrsni kompleksni znakovi, znakovi složenog karaktera, više funkcionalni obrasci nego strukturalni modeli ili semantičke datosti. ${ }^{\prime 13} \mathrm{R}$. Bugarski u svom djelu Uvod u opštu lingvistiku o tome kaže: "Prilikom upotrebe jezika, kroz nizanje međusobno povezanih rečenica, ostvaruju se veće komunikacijske cjeline. Realizacija jezika u vezanom govoru obično se naziva diskurs ako je riječ o procesu a tekst ako se radi o proizvodu, ali se ovi dosta neodređeni termini upotrebljavaju $i$ kao približni sinonimi."14 Bugarski ovu svoju definiciju pobliže određuje u djelu Jezici gdje kaže: "Standardni jezici imaju stručno kodifikovan $i$ društveno sankcionisan oblik; oni služe za kultivisanu javnu upotrebu u svim domenima, kao komunikacijski instrument savremenog života. Pošto su po svojoj prirodi polufnukcionalnog karaktera, u njima se razvijaju različiti funkcionalni stilovi ili registri-varijateti određeni predmetno $i$ situaciono."15 Asher za diskurs kaže: "Važno je termina diskurs, kao brojna imenica on znači relativno diskretan podskup cijelog jezika koji se upotrebljava u specifične socijalne ili institucionalne svrhe. ${ }^{116}$

Pojam diskurs etimološki potječe od latinske riječi discursus, a u poznatom Simeonovom Rječniku lingvističkih termina se determinira kao: rastaka, razgovor, govor, raščlanjivanje razumom, promišljen, koji se izvodi pomoću razumnog raščlanjivanja. Kako onda shvatiti diskurse? Termin diskurs je vrlo značajan proizvod sociolingvistike i njime se označava leksika, ponekad i gramatika specifična kakvoj ljudskoj djelatnosti, profesionalnoj ili amaterskoj. Tradicionalni pojam

\footnotetext{
${ }^{12}$ Glovacki, Bernardi, Kovačec, Mihaljević, Halwachs, Soring, Penzinger, Schrodt, Uvod u lingvistiku, Školska knjiga, Zagreb, 2001., str., 191.

13 M. Radovanović, Sociolingvistika, Književna zajednica Novog Sada, Novi Sad, 1986., str. 12.

${ }^{14}$ R. Bugarski, Uvod u opštu lingvistiku, Čigoja, Beograd, 1996., str. 226.

${ }^{15}$ R. Bugarski, Jezici, Čigoja, Beograd, 1997., str. 69.

${ }^{16}$ M. Katnić-Bakaršić, Stilistika, Ljiljan, Sarajevo, 2001., str. 64.
} 
stila moderna sociolingvistika ograničava na varijacije u upotrebi jezika koje odgovaraju raznim situacijama na skali formalnoneformalno. Međutim, oni potpuno ne odbacuju ni pojam funkcionalnog stila, koji se može upotrijebiti u smislu diskursa ili registra, iako on nije općeprihvaćen termin u sociolingvistici ali je po mišljenju većine nepotreban. U novije vrijeme nam se nameće definicija registara kao distinktivnih osobina jezičkih varijanata koji zavise od vanjezičkih utjecaja. Osim ovakvog shvatanja javlja se i vrlo rasprostranjeno identificiranje registra sa funkcionalnim stilovima:"Tipična upotreba jezika u tipičnoj sociokulturnoj situaciji naziva se funkcionalnim stilom (registrom, varijetetom)."17, a neki lingvisti (Flower) registrima označavaju samo specijalizirane vrste tekstova, dakle gotovo poistovjećuju registar sa žanrom. Nasuprot ovakvom mišljenju mnogi lingvisti smatraju da registar nije ekvivalentan funkcionalnom stilu. Tošović kaže: "Pošto neki upotrebljavaju riječ registar kao sinonim za funkcionalni stil, potrebno je reći da to ne mogu biti istoznačni pojmovi. Onako kako se sad koristi, registar podrazumijeva i ono što je funkcionalni stil i ono što nije funkcionalni stil, podrazumijeva veoma široku diferencijaciju jezika (socijalno-psihološku i situaciono-komunikativnu). Njegov je nedostatak $i$ u tome što ne dolazi iz lingvističkih škola koje su fundirale ovo učenje o stilu, što je manje stilistički, a više sociolingvistički termin." 18 Ovakva neslaganja oko same terminologije, proizlaze iz dubljih uzroka. Termin funkcionalni stil proizvod je slavenskih lingvističkih škola, i upravo zbog toga većina slavenskih lingvista isuviše kruto prihvata ovaj pojam i ne dozvoljava njegovu zamjenu pojmom registar, koji je proizišao sa zapadnoevropskog terena, gdje se funkcionalno-stilski problemi uglavnom posmatraju u okviru sociolingvistike. Upravo zbog toga, većina pristalica slavenskih lingvističkih škola smatraju da je pojam registra nadišao samo značenje funkcionalnog stila, što je rezultat posmatranja registra više u sferi opće lingvistike, teorije komunikacije i semiotike, a ne same stilistike, tako da je i samo značenje ovog pojma znatno šire nego sam pojam funkcionalnog stila, i zbog toga oni nikako ne mogu biti sinonimi. Kod nekih anglosaksonskih lingvista

\footnotetext{
${ }^{17}$ R. Hadžiefendić-Parić, Naš jezik, Sarajevo Publishing, Sarajevo, 2003., str. 32.

18 B. Tošović, Funkcionalni stilovi, Institut für Slawistik der Karl-Franzens-Uniwersität Graz, Grac, 2002,str., 31.
} 
(Turner) javlja se specifična terminologija, tako oni o registrima govore u smislu opozicije formalnih i neformalnih registara, koje nazivaju stilom, a samo specijalizirane varijetete nazivaju registrima. Međutim ako shvatimo registar kao funkcionalni stil nužno se susrećemo sa onim što se označava kao registarski signal, odnosno susrećemo se sa zbirom onih osobina koji neki registar distinktivno odvajaju od drugog, a sve registre koji imaju otprilike tačno utvrđene, formalizirane registarske signale možemo odrediti kao hegemonijske registre (monoregistre), dok sve ostale u kojima možemo prepoznati miješanje različitih signala određujemo kao heteroglosijske registre (multiregistri). U Uvodu u lingvistiku, grupe autora, Dieter W. Halwachs za determinaciju pojma registar uzima onu definiciju koju daje poznati sociolingvist Denison: "Registar je svaki od dijatipskih varijeteta za koji članovi određene govorne zajednice obično smatraju da pripadaju jednom jeziku." 19

Hollidy za registar kaže: "Registar je konfiguracija značenja koja se tipično asociraju specifičnom situacionom konfiguracijom konteksta. Sam situacioni kontekst razlikuje se po tri tipa elementa: field, tj. područje (šta se događa i gdje), tenor, tj. sadržaj(sudionic -tip odnosa među njima, govorne i situacione uloge), mode, tj. način (kakav je jezik, koja mu je uloga, da li je persuasivno ili referencijalno ili pak emocionalno orijentiran usmeno ili pismeno, kojim tipovima konektora je organiziran tekst..."20

Iz svih različitih tumačenja pojmova diskurs i registar, možemo zaključiti da supstitucija pojmova nije riješila problem oko terminologije, jer je očigledno veliko variranje značenjskih determinacija ovih pojmova. Bez obzira koje termine koristili, najvažnije je da uočimo da jezik nije zatvoreni, kruti sistem, nego on predstavlja sistem prepun različitih varijacija. Ako shvatimo jezik kao jedan organiziran sistem (kod) vrlo lako možemo uočiti da se on sastoji od mnoštva podsistema (potkodova). Međutim, i tu se javlja problem, koji možemo označiti kao jednu čestu lingvističku boljku, a to je problem terminologije. U većini literature susrećemo se sa pojmom raslojavanja jezika, i odmah se, imajući u vidu varijabilnost

\footnotetext{
${ }^{19}$ Glovacki, Bernardi, Kovačec, Mihaljević, Halwachs, Soring, Penzinger, Schrodt, Uvod u lingvistiku, Školska knjiga, Zagreb, 2001., str., 203.

${ }^{20}$ M. Katnić-Bakaršić, Stilistika, Ljiljan, Sarajevo, 2001., str. 36.
} 
jezika kao sistema, moramo zapitati da li ovaj termin uopće odgovara samom procesu variranja jezika, jer ako govorimo isključivo o raslojavanju jezika mi naprosto zanemarujemo isto tako važan proces, drugu stranu medalje, koju bismo mogli označiti kao integriranje i preplitanje jezičkih potkodova unutar jezika kao jedne cjeline sistema (koda). Upravo zbog ovakve "skučenosti" sintagme raslojavanje jezika, kod anglosaksonskih lingvista nalazimo sintagmu jezičko variranje (language variation), koja je po mom mišljenju kompetentnija za označavnje pojave o kojoj govorimo, ali u lingvistici širom svijeta i dalje ostaje kao općeprihvaćena sintagma-jezičko raslojavanje. Postoje različiti načini klasifikacije raslojavanja jezika, međutim najznačajniji tip jezičkog raslojavanja za stilistiku je funkcionalno raslojavanje. B. Tošović je na lijep način definisao uzroke funkcionalnog raslojavanja jezika: "Ako bismo išli od užeg ka širem, onda bismo kazali: Funkcionalni stil je u jeziku, jezik je u čovjeku, čovjek je $u$ društvu". ${ }^{21}$ Primarni uzroci funkcionalnog raslojavanja jezika proizlaze iz ekstralingvističkih faktora (društvene aktivnosti i društvene okolnosti), a sekundarni uzroci nastaju pod njihovim utjecajem i predstavljaju intralingvističke faktore. Dakle jednostavnije rečeno osnovni uzroci funkcionalnog raslojavanja jezika proizlaze iz čovjekovog nastojanja da u različitim sferama svog društvenog života komunicira na najbolji mogući način. Da na najbolji mogući način, prenese poruku preko komunikacijskog kanala do određenog recipijenta, koji ovisno od društvene situacije očekuje poruku koja je formalno oblikovana i koja odgovara datim sociokulturnim uslovima. Ako poruka nije formalno oblikovana, funkcionalno-stilski određena, logično je da će doći do smetnje u komunikaciji. Dakle, različite sfere društvenog života naprosto zahtijevaju i funkcionalno raslojavanje jezika, te stoga svakako možemo tvrditi da primarni uzroci funkcionalnog raslojavanja leže $\mathrm{u}$ ekstralingvističkim faktorima, a da je njihova osnovna svrha što jasnija komunikacija. O tome M. N. Kožina kaže: "Jedan od kriterija, principa podjele (određivanja $i$ klasifikacije funkcionalnih stilova) jeste pripadnost govornog sistema navedenom kompleksu (jedinstvu)

\footnotetext{
${ }^{21}$ B. Tošović, Funkcionalni stilovi, Institut für Slawistik der Karl-Franzens-Universität Graz, Grac, 2002., str. 52.
} 
ekstralingvističkih baznih faktora, koji i uslovljavaju specifičnost govornog sistema stila,odnosno, u pravom smislu, sam stil.

DRUŠTVENE OKOLNOSTI I AKTIVNOSTI DRUŠTVENE OKOLNOSTI I AKTIVNOSTI

POŠILJALAC KOMUNIKACIJSKI KANAL RECIPIJENT PORUKA

DRUŠTVENE OKOLNOSTI I AKTIVNOSTI DRUŠTVENE OKOLNOSTI I AKTIVNOSTI

Međutim, ne možemo same funkcionalne stilove shvatiti kao krute i potpuno zatvorene, jer je očigledno da se dešava ono što možemo nazvati preregistracijom registara. Odnosno dešava se ona pojava, koju najbolje možemo determinirati sintagmom unutarjezičko variranje (languige variation). Unutar jednog standardnog jezika, kao koda, koji se sastoji od niza potkodova, koji su rezultat fukcionalnog raslojavanja, nužno mora doći do preplitanja i integriranja potkodova unutar koda, a pri tom procesu preplitanja upravo se dešava jezičko variranje koje može, ali i ne mora obuhvatiti preregistraciju registara. O utjecaju ekstralingvističkih faktora (društvenih aktivnosti i društvenih okolnosti) predstavnik postmoderne stilistike, Brich kaže: "Postmoderna stilistika, koja je po pravilu dio socijalne semiotike, smatra da u svakom društvu možemo govoriti o ideološkim implikacijama pojedinog registra (nema "nevinog" izbora, tvrdi se). Budući da neki registri (ili stilovi) počinju dominirati nad drugima, to izaziva reakciju manje "prestižnih" registara, te proizvodi "borbu za moć", koja rezultira u ideološki konfliktnim registrima, ideološki različitim sistemima klasificiranja i kontroliranja svijeta. ${ }^{223}$ Dakle, sveukupna čovjekova jezička komunikacija unutar jednog standardnog jezika, koda, funkcionalno se raslojava na potkodove (funkcionalne stilove, registre), upravo zahvaljujući čovjekovoj društvenoj determiniranosti u pojedinim intervalima njegovih uloga u društvu, koje su radi čovjekove interakcije u širu društvenu zajednicu uvijek, manje ili više formalno određene. Što se tiče same klasifikacije funkcionalnih stilova donedavno je vladala tradicionalna klasifikacija,

${ }^{22}$ B. Tošović, Funkcionalni stilovi, Institut für Slawistik der Karl-Franzens-Universität Graz, Grac, 2002., str. 53.

${ }^{23}$ M . Katnić-Bakaršić, Stilistika, Ljiljan, Sarajevo, 2001. str., 37. 
koja je bila prihvaćena širom svijeta, a po kojoj se razlikuje pet stilova:

1. književnoumjetnički funkcionalni stil

2. novinarsko- publicistički funkcionalni stil

3. administrativno-pravni funkcionalni stil

4. naučni funkcionalni stil

5. razgovorni funkcionalni stil

Ova klasifikacija na pet osnovnih stilova nastaje u ruskoj lingvistici, a prihvataju je i češka i slovačka lingvistička škola. Mistrik prije klasifikacije funkcionalnih stilova, vrši podjelu stila na: individualni stil, koji predstavlja zajednička obilježja u iskazu jednog autora, interindividualni stil, koji predstavlja zajednička obilježja u jezičkim izrazima raznih autora i stilove pojedinačnih konkretnih iskaza. Ovu klasičnu klasifikaciju u novije vrijeme proširuju mnogi autori uvodeći različite novine, bilo u izdvajanju novih stilova, bilo podstilova.

\section{RELIGIJSKI FUNKCIONALNI STIL}

Ono što možemo uočiti u Tošovićevom grafikonu klasifikacije funkcionalnih stilova je to da on pored pet tradicionalnih stilova uvodi i šest međustilova, a to su: scenaristički, esejistički, reklamni, memoarski, oratorski $i$ epistolarni. Pored toga, vrlo značajna novina koju on unosi je i izdvajanje sakralnog funkcionalnog stila, koji on doduše ne izdvaja kao samostalni funkcionalni stil nego mu daje mjesto u pretklasifikaciji u smislu opozicije profano/sakralno.

U samoj klasifikaciji funkcionalnih stilova, religijski stil je dugo vremena bio zanemarivan i nepriznavan kao zaseban funkcionalni stil. Uglavnom se izučavao u sklopu književnoumjetničkog stila (D. Crystal smatra da je religijskom funkcionalnom stilu mjesto unutar književnoumjetničkog stila $\mathrm{i}$ da se treba izučavati ravnopravno $\mathrm{s}$ njim). Za razliku od ovakvog stava imamo autore koji priznaju religijski stil ali na taj način da mu daju mjesto u pretklasifikaciji na religijski i profane stilove, nakon koje bi slijedila klasifikacija funkcionalnih stilova koja bi obuhvatala samo profane stilove. Ovakav stav ima i Tošović koji kaže: "Recimo, ukoliko je religija kao oblik 
društvene svijesti dosta razvijena $i$ u datom kolektivu predstavlja važan činilac, doći će do raslojavanja jezika na opozicionoj ravni vjersko $<\longrightarrow>$ svjetovno, što je bilo posebno karakteristično za početne periode razvoja čitavog niza jezika. Danas su u mnogim dijelovima svijeta religiozni krugovi razvili široku aktivnost, posebno izdavačku, utičući na stvaranje posebnog oblika kazivanja - religijskog. ${ }^{24}$

Za priznavanje i izdvajanje religijskog funkcionalnog stila svakako je najznačajniji engleski lingvist Najer koji je 1981. godine po prvi put izdvojio ovaj stil kao zaseban i nazvao ga religijskim. Najer kaže: "Religiozni stil engleskog jezika također je, očigledno, vrsta engleskog književnog jezika koja se koristi u specifičnoj oblasti komunikacije, koja ima jasnu (funkcionalnu) usmjerenost na prodiranje ili ispoljavanje religiozne svijesti posredstvom intenzivnog emocionalnog djelovanja ili izražavanja volje $i$ koja se odlikuje određenim sistemom jezičkih sredstava. Po svoj prilici, za suvremeno stanje engleskog jezika i odgovarajućeg društva ova stilistička vrsta nipošto nije postala relikt, jer je religiozna propaganda, bez obzira na intenzivan razvoj sredstava svjetovne buržoaske propagande, na širenje prosvjete, naučnih saznanja i progresivnih ideja, očigledno, ne namjerava da još prepusti svoje pozicije. ${ }^{\prime 25}$ I oko samog naziva ovog funkcionalnog stila imamo problema oko terminologije. U mnogobrojnoj literaturi možemo naći termine: vjerski stil, religiozni stil, biblijski stil $i$ sakralni stil. Međutim, svakako je logično da ne možemo prihvatiti termin biblijski stil, jer religijski stil obuhvata bezbroj svetih tekstova ali i usmenih vrsta, koji su van biblijske znanosti, ali postavlja se pitanje šta je sa terminima vjerski, religijski i sakralni stil. Neki autori izdvajaju religijski funkcionalni stil, ali ga nazivaju sakralnim, npr. Webster, koji kaže: "Sakralni funkcionalni stil naziva se još $i$ vjerskim, odnosno religijskim stilom, tj. jezikom ili varijetetom.'

I M. Katnić-Bakaršić izdvaja religijski funkcionalni stil, ali ga naziva sakralnim. Ona kaže: "Činjenica jeste da je ovaj stil specifičan u poređenju sa svim drugima profanim, dakle, ne-sakralnim stilovima,

\footnotetext{
${ }^{24}$ B. Tošović, Funkcionalni stilovi, Institut für Slawistik der Karl-Franzens -Universität Graz, Graz, 2002., str. 55.

${ }^{25}$ Ibid., str. 55.

${ }^{26}$ M. Katnić-Bakaršić, Stilistika, Ljiljan, Sarajevo, 2001., str. 70.
} 
ali to nije razlog da se on izostavlja iz klasifikacije funkcionalnih stilova... Zbog toga će se sakralni stil u ovoj knjizi posmatrati kao jedan od funkcionalnih stilova koji ima tačno određenu sferu upotrebe, svoje jezičko-stilske jedinice $i$ namijenjen je tačno određenoj skupini ljudi u društvu, a sreće se i kod drugih članova zajednice. ${ }^{127} \mathrm{Tu}$ se naprosto moramo zapitati o valjanosti ovog pojma, koji mnogi koriste kao sinonim za religijski funkcionalni stil. Etimološki gledano riječ sakralno potječe iz latinskog jezika od riječi sacer, sacra, sacrum, a znači onaj koji se odnosi na svete radnje, na crkvene obrede. Dakle, da bi nešto bilo sakralno mora biti i sveto, mi svakako možemo govoriti o svetim tekstovima i tada bi ovaj termin bio valjan, ali ako imamo u vidu da u religijski funkcionalni stil spadaju i npr. propovijedi ili vazovi ili psalmi i kaside, logično je da zaključimo da ove vrste same po sebi nisu svete (da bi nešto bilo sveto mora proći fazu posvećenja) i prema tome ovaj je pojam preuzak da obuhvati sve ono što spada u religijski stil, jer on obuhvata pored onog što možemo označiti kao sveto i ono što možemo označiti kao nesveto. O skučenosti pojma sakralno u smislu označavanja religijskog funkcionalnog stila R. Hadžiefendić-Parić kaže: "Ponegdje se imenuje kao sakralni (lat. Sacralis, koji se tiče crkvenih obreda), a sakralnost se stječe posvećenjem. Zbog toga su nazivi za ovaj stilreligijski ili vjerski-općiji nego naziv sakralni." ${ }^{12}$ Prema tome, možemo vrlo lako zaključiti da su najkompetentniji termini za imenovanje ovog funkcionalnog stila, termini vjerski ili religijski. Riječ religija etimološki potječe iz latinskog jezika od riječi religio, a doslovno se prevodi kao vjera, vjeroispovijest, a sam pridjev religijski, analogno tome se prevodi kao vjerski, vjeroispovjedni. Na osnovu toga, možemo zaključiti da se pojmovi sakralni, vjerski i religijski ne mogu koristiti kao sinonimi, jer riječ sakralno ima dosta uže značenje od pojmova religijski i vjerski, koji u sebi obuhvataju i sakralno i nesakralno, i koji bi se već mogli smatrati sinonimima, te su svakako kompetentniji za imenovanje ovog funkcionalnog stila koji obuhvata sve sfere vjerskog (religijskog) života.

\footnotetext{
${ }^{27}$ Ibid., str. 70.

${ }^{28}$ R. Hadžiefendić-Parić, Naš jezik, Sarajevo Publishing, Sarajevo, 2003., str. 47.
} 


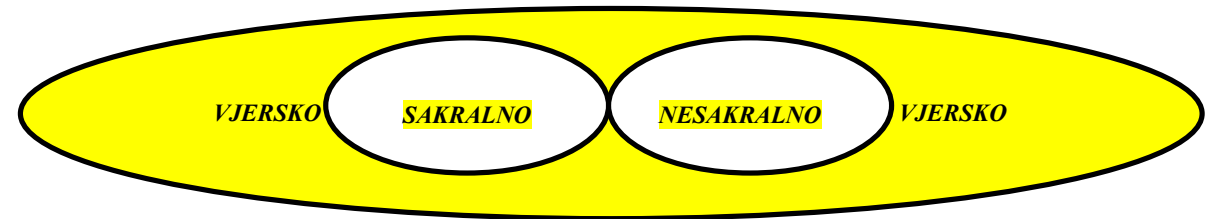

Pojmom religijski funkcionalni stil možemo označiti raznoliku upotrebu jezika vezanu za vjersku sferu društvenog života. Cjelokupnu tu sferu možemo determinirati kroz dvije relacije, relaciju "odozgo na dolje", koja bi obuhvatala sve one tekstove kojima se pripisuje božanska umiješanost pri nastanku i relaciju "odozdo na gore", koja bi obuhvatala svu onu upotrebu jezika koja je usmjerena prema Bogu ili različitim božanstvima. Ovakvu dvostruku relaciju religijskog funkcionalnog stila navodi R. Hadžiefendić-Parić:"To je stil vjerskih knjiga, poslanih ljudima usmenim putem kao objava (odozgo-na dolje) - stil Starog i Novog zavjeta, stil Kur'ana kao i stil tekstova drugih religija, sekti $i$ vjerskih učenja. To je, općenito, stil tekstova i govora (obraćanja) kojim se vjerski službenici obraćaju drugim ljudima-vjernicima (propovijedi, hutbe, vazovi), stil obavljanja molitvi i obreda-kada se vjernici obraćaju Stvoritelju, Bogu (odozdo prema gore) ${ }^{\prime 29}$ M. Katnić-Bakaršić navodi definiciju koju je dala Mečakovskaja: "Sakralni stil obuhvata sferu usmene $i$ pismene religijske komunikacije, tako da je žanrovski veoma raznorodna-počev od svetih knjiga različiti religija pa do jezika i stila izvođenja religijskih obreda, molitvi, obraćanja vjerskih službenika vjernicima $i$ slično. ${ }^{130}$ Ova definicija koja je dala Mečakovskaja, nam lijepo definira religijski funkcionalni stil. Dakle, pod pojmom religijski funkcionalni stil podrazumijevamo i pismenu i usmenu upotrebu jezika u svim sferama religijskog života.

\section{Tekstostilistički nivo analize retoričkih islamskih religijskih tekstova}

Riječ hutba etimološki potječe iz arapskog jezika i doslovno znači govor koji se održava u naročitim slučajevima radi ostvarivanja određenih ciljeva, a onaj koji drži takav govor naziva se hatib-govrnik.

\footnotetext{
${ }^{29}$ R. Hadžiefendić-Parić, Naš jezik, Sarajevo Publishing, Sarajevo, 2003., str. 47.

${ }^{30}$ M. Katnić-Bakaršić, Stilistika, Ljiljan, Sarajevo, 2001., str. 70.
} 
Dakle, osnovna funkcija hutbi je konativna, odnosno ubjeđivačka i slobodno možemo reći da hutbe kao islamski propisi imaju zadatak da muslimane ali i nemuslimane poučavaju vjeri, odnosno ubjeđuju ih $\mathrm{u}$ ispravnost islamske vjere. Poznati mulaim Mehmed ef. Handžić u svom djelu Rasprave eseji članci, u odlomku O hutbi kaže: "Imademo hutbi koje su vezane za određeno vrijeme, a imade ih i nevezanih. Nevezane su hutbe kao vaz ili propovijed $i$ drže se uvijek, čim govornik opazi kakvu priliku za to. Hutbe vezane za određeno vrijeme su kao hutba u petak uz džumu-namaz ili kao hutba uz dva bajrama ili kao hutbe što se drže za vrijeme hadža itd. ${ }^{131}$ Dakle, po ovakvoj podjeli imamo prave hutbe, one koje su vremenski vezane za neki od značajnijih vremenskih termina po islamu i vremenski nevezane hutbe, koje se najčešće označavaju terminom vazovi (propovijedi) i koje je poželjno koristiti što češće neovisno od vremena, a sve s određenom ubjeđivačkom ulogom. Za razliku od ostalih vjerskih žanrova hutba je zahvaljujući svom oratorskom vidu donekle oslobođena nužnosti uklapanja u tačno određene formulare, odnosno hutib ima ograničenu slobodu pri izboru konstituenta za svoju hutbu, ali ipak i ovdje postoje tačno utvrđeni konstitucioni elementi koje hutba mora sadržavati, a to su:

1. zahvala Bogu (hamd)

2. salevât na Alejhisselama

3. savjet prisutnima i prikladna propovijed zasnovana na temelju nekog kur'anskog ajeta

4. molitva (dova) za muslimane

Pored ova četiri osnovna konstituenta hutbe koje je izdvojio ef. Handžić on navodi i mišljenje većine fakiha koji smatraju da hutba da bi bila valjana mora zadovoljiti sljedećih petnaest uputaka:

1. da hatib za vrijeme hutbe bude s abdestom i pripravan za namaz

2. da prije hutbe sjede na minberu

3. da se pred njim prouči ezan prije hutbe kao i ikamet nakon hutbe

31 M. Handžić, O hutbi, Eseji, rasprave, članci, Izabrana djela, knjiga VI, Baština, 1999., str.70. 
4. da ustane na noge i okrene se prema prisutnima

5. da započne hutbu sa zahvalom (hamd) i pohvalom (senâ)

6. da prouči kelimei - šehâdet

7. da prouči salevât Pejgamberu

8. da savjetuje i opominje prisutne

9. da prouči makar jedan ajet iz Kur'ana

10. da hutbu razdijeli na dva dijela, ili bolje reći, da održi dvije hutbe

11. da te dvije hutbe rastavi kratkim sjedenjem

12. da $i$ na početku druge hutbe izrazi zahvalu i pohvalu Bogu $i$ salevât Pejgamberu

13. da u ovoj hutbi moli i dovu čini muslimanima i da im Bog čini oprosta (istigfâr)

14. da hutbu drži glasno, kako bi ga prisutni mogli razumjeti i čuti

15. da hutbu sasvim ne odulji

Ono što se bitno promijenilo kod hutbi, kroz njen historijski razvoj je to što su one $u$ prošlosti $u$ cijelosti bile propovijedane isključivo na arapskom jeziku, a ako uzmemo u obzir činjenicu da stanovništvo u većini islamskih zemalja nije poznavalo arapski jezik , možemo zaključiti da su one bile tim ljudima potpuno nerazumljive. Kako je osnovna svrha hutbe propovijed i savjet, logično je da je moralo doći do radikalnijih promjena u krutom stavu da je hutba jedino valjana na arapskom jeziku. Međutim u svijetu islamskih učenjaka vlada podijeljeno mišljenje oko upotrebe arapskog jezika. M. ef. Handžić navodi mišljenje nekolicine: "Ebu Hanife drži da je hutba valjana $i$ drugim jezikom, pa znao hatib održati hutbu arapskim jezikom ili ne znao. Ebu Jusuf i Muhammed drže, da je hutba drugim jezikom osim arapskog valjana samo u tom slučaju ako hatib ne bi znao održati hutbu na arapskom jeziku. U protivnom slučaju hutba ne vrijedi. ${ }^{32}$

${ }^{32}$ M. Handžić, O hutbi, Eseji, rasprave, članci, Izabrana djela, knjiga VI, Baština, 1999.,str. 72. 
Dakle, dok neki smatraju da je uvjet valjanosti hutbe arapski jezik, drugi smatraju da bi samo bilo poželjno koristiti arapski jezik, ali ako je on hatibu ili vjernicima nerazumljiv hutba se može držati i na nekom drugom jeziku, pod uslovom da se ajeti iz Kur'ana čitaju na arapskom, a postoji i manjinsko mišljenje da hutbu treba držati na arapskom, ali je nakon toga treba protumačiti vjernicima na njima razumljivom jeziku. Kroz ovaj kratak presjek mišljenja nekoliko islamskih učenjaka možemo uočiti pojavu koja je specifična za većinu vjerskih zajednica, a to je pojava borbe za očuvanje izvornog jezika svetih knjiga i tekstova.

\section{a) JAKE POZICIJE TEKSTOVA HUTBI: 1) NASLOV}

Naslov je u stilističkoj analizi vrlo značajan i predstavlja prvu jaku poziciju teksta. Pri sastavljanju propovijedi hatib, kao produktor teksta, polazi od činjenice koja se sastoji od želje da što sažetije i konkretnije pruži prvu, osnovnu informaciju o sadržaju teksta hutbe/vaza (referencijalna funkcija naslova), a sve s ciljem da privuče pažnju recipijenata (vjernika), što ujedno predstavlja konativnu funkciju. Sam naslov hutbe nam govori da li se radi o vezanom tipu hutbe (vremenski vezana) ili o nevezanom tipu hutbe.

\section{2) HAMD I SALEVÂT}

Odmah nakon naslova, kod hutbi možemo uočiti shematizirani početak, tipa:

Hvala Allahu, Stvoritelju svjetova, na milosti i nimetima kojima nas daruje. Donesimo salavat $i$ selam na posljednjeg Allahovog poslanika Muhammeda (a.s.), na njegovu porodicu, na njegove ashabe $i$ na sve one koji su živjeli $i$ umrli sa istinom u srcu $i$ djelu. Sjetimo se bosanskih sinova, šehida, koji su, na Allahovom putu, dali svoje živote.

Sve hutbe, počinju klišeizirano, zazivanjem Božijeg imena, onim što zovemo ivokatio divina, što je specifično za većinu vazova, a sama tradicija invokacije u islamu javlja se još od srednjeg vijeka i gotovo svi pisani tekstovi tog vremena počinju upravo na ovaj način. Za razliku od invokacije u kršćanskom svijetu, u islamu ona uvijek 
podrazumijeva pored zahvale Bogu (hamd) slavljenje poslanika Muhammeda pa i njegove porodice (salevât). Ono po čemu se invokacija promijenila kako je preuzeta u oratorskom vidu je to što se izostavlja nekadašnji sastavni dio, karakterističan za pisane tekstove, a taj dio je sam potpis autora uz obavezan epitet (tipa: rob Božiji, ubogi, siroti), koji je imao zadatak da izrazi autorovu malenkost $\mathrm{i}$ beznačajnost $\mathrm{u}$ odnosu na Svevišnjeg. Donošenje salevâta na Njegovog poslanika Muhammeda i njegovu porodicu također predstavlja uobičajenu tradicionalnu formu u islamskom svijetu, a sam pojam donošenje salevâta podrazumijeva želju da se da zajamčeno i obećano mjesto Poslaniku, te da mu se Allah smiluje i nagradi onozemaljskim užicima. Sama invokacija zajedno sa selavatom također predstavljaju jaku poziciju teksta i ima konativnu funkciju (zadatak da privuče pažnju vjernika).

\section{3) IMENOVANJE U TEKSTU HUTBE}

Odmah nakon uvoda, već od prvih rečenica, u funkciji jakih pozicija analiziranih tekstova, možemo uočiti riječi koje su orijentalnog porijekla i koje se mogu nazvati islamskim vjerskim terminima (Ramazan, kandilji, minaret, mujezin, džamija, Bajram, muhadžiri, šehidi, alejhisselam...) Inače su tipovi ovakvih izraza na izvornom jeziku uobičajeni za gotovo sve religije (hebrejski, staroslavenski, latinski), ali ono što je specifično za ove termine nabrojane $u$ ovoj hutbi je to da su se takve riječi udomaćile $u$ bosanskome jeziku i da su one razumljive i široj društvenoj zajednici a ne samo ograničenom krugu-vjernika i vjerskih službenika što je slučaj kod većine ostalih religija.

\section{4) STILSKE FIGURE I TROPI}

Možemo uočiti vrlo veliki broj antonima (grč. anti-protiv, onoma-ime, riječi koje imaju suprostavljeno značenje): dobra/zlom, pravde/nasiljem, svjetla/mrakom, ranjeno/izliječiti, uznemirene/mir, porušeni/popraviti, zamračeni/osvijetliti, vjeruju/ne vjeruju, mrak/svijetlo, zlo/dobro, nasilje/pravda, pravovjerje/krivovjerje, mudrost/nerazumnost, vjerovanje/ nevjerovanje, prirodno/neprirodno, iskrenom/laž, posljedica/uzrok, nerazumnost/mudrošću... Na osnovu antonima konstruiše se posebna vrsta poredbe, koja se zasniva na 
suprotnostima, a koja se označava terminom antiteza (grč. antithesis, suprotnost, suprotstavljanje). Upravo na osnovu distinkcije između pojmova na kojima se ustvari temelji cjelokupni jezički sistem, utemeljuju se određena značenja i zato se korištenjem antiteze mogu postići vrlo efektivne značenjske nijanse. Pored suprotstavljanja značenja riječi ona obuhvata suprotstavljanje cjelokupnih rečenica. Tada možemo govoriti o kontradiktornim rečenicama: "Kontradiktorne rečenice su one u kojima se predikatima iskazuju suprotne tvrdnje: da nešto jeste $i$ nije u isto vrijeme. Kontradiktornost se javlja kada se, uz isti subjekat, na mjestu predikata pojave antonimi ili suprotstavljena značenja". ${ }^{33}$ Sljedeća karakteristična osobina koju često možemo uočiti u tekstovima hutbi su paralelizmi (različita ponavljanja), čija je osnovna svrha posebno isticanje značenja pojedinih riječi, čime se želi istaknuti njihov naročiti smisao i važnost. Možemo lako zapaziti učestalo korištenje figure konstrukcijepolisindetona (grč. polysýndeton, mnogo vezano), koja podrazumijeva nizanje veznika bez gramatičke potrebe (dominiraju tri veznika: $i, n i$ $d a$ ). Osim polisindetona, možemo uočiti vrlo učestalo ponavljanje riječi na početku rečenice- anafora (grč. anaphorá, nanošenje, ponavljanje) i riječi unutar rečenice.

Na primjer :

Nadamo se da će ova poruka doći do vas i da nećete zaboraviti

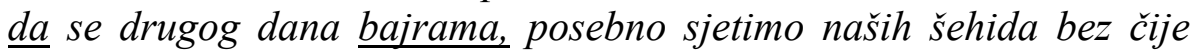
žrtve ne bi bilo ni Bosne, ni u Bosni Ramazana, ni Bajrama. Sad kad

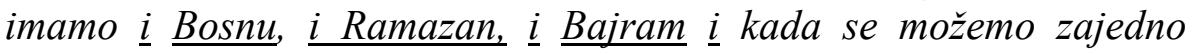
radovati

Vjerovati znači znati da Ademova, alejhisselam, istina pobijedila Iblisovu laž; da je Ibrahimovo, alejhisselam, pravovjerje nadvladalo Nemrudovo krivovjerje; da je Musaova; alejhisselam. nada u pomoć Božiju nadživjela faraonovo nasilje; $\underline{d a}$ je Muhammedova, alejhisselam, mudrost porazila Ebu Džehelovu nerazumnost. Vjerovati znači da laž nije istina; da mrak nije svjetlo; $\underline{d a}$ zlo nije dobro; da nasilje nije pravda; $\underline{d a}$ nerazumnost nije mudrost.

${ }^{33}$ R. Hadžiefendić-Parić, Naš jezik, Sarajevo Publishing, Sarajevo, 2003., str. 21. 
Dalje možemo primijetiti da se javlja određeni broj obaveznih epiteta (grč. epítheton, dodatak), koji su specifični za islamsku religiju uopće (Adem alejhisselam, Ibrahim, alejhisselam, Musa alejhisselam, Muhammed alejhisselam). Epitet alejhisselam etimološki potječe iz arapskog jezika i doslovno znači "neka je blagoslovljen", a obavezan je u islamu svaki put kad se pominju imena Božijih poslanika. U smislu figure epiteti predstavljaju riječi koje se dodaju uz imenice da bi se omogućilo stvaranje što jasnije slike imenovanog, ili neke specifične osobitosti imenovanog, što je ovdje slučaj. Zatim možemo uočiti primjenu figura riječi (tropa), metafore (grč. metá, preko i phérō, nosim; metaphorá, prijenos) i alegorije (grč. állos, drugi i agoreúō, govorim).

Na primjer:

Vjerovati znači znati da nije isti onaj koji je temelj zgrade svoje postavio na Božijem zadovoljstvu i onaj koji je temelj zgrade postavio na rubu podlokane obale što se nagela da se zajedno s njim sruši u provaliju. Bog neće ukazati na pravi put narodu koji sam sebi nepravdu čini. U zgradi koja se gradi bez vjere čovjek nema mira.

Ono što je specifično za metaforu u islamskom svijetu je da metafora nije više samo figura riječi, nego ona mistično postaje figura djela.

\section{INKOATIVNA I FINITIVNA REČENICA}

U samom uvodu hutbi javlja se ono što je specifično i za propovijedi a to je inkoativna rečenica:"Draga braćo $i$ sestre"! Međutim, ova rečenica svakako ima svoje logičko opravdanje zašto je postala obavezan dio uvoda obraćanja vjerskih službenika vjernicima. Ona nam u neku ruku govori svojatačkim tonom o određenoj zatvorenosti pojedine vjerske zajednice i stvara kod vjernika sigurnost i viziju o integraciji u zajednicu, o jednom tijelu sve braće i sestara po vjeri. Dakle, osnovne funkcije ove sintaksičke konstrukcije su konativna i anforička (otvaračka) funkcija.

\section{STILISTIČKI TEKSTUALNI KONEKTORI}

U tekstu analiziranih hutbi/vazova, kao najfrekventniji stilistički konektor javlja se anafora. Međutim, pored anafore funkcije 
stilističkih tekstualnih konektora vrše i epifore, polisidenti (učestalo ponavljanje istog veznika), gradacija, retoričko obraćanje i eksklamacija, sineterzam, kumulacija idr.

\section{b) OSOBINE RELIGIJSKOG STILA: 1. BOŽANSKA DATOST JEZIKA}

Prije iznošenja samih osobina religijskog funkcionalnog stila bitno je dati pregled o samim shvatanjima jezika kao božanske datosti, jer takvo shvatanje uveliko oblikuje sam religijski stil i može se slobodno reći da čini njegovu polaznu tačku. Ako zanemarimo evolucionističke teze i zaronimo u shvatanje nastanka onog što se $u$ lingvistici najčešće označava terminom prirodni jezik možemo pronaći razne teorije o božanskom porijeklu jezika. Pokušaje odgovora na pitanje nastanka jezika nalazima u najstarijim svetim tekstovima i knjigama.

\section{U početku bijaše Riječ}

I Riječ bijaše kod Boga-

I Riječ bijaše Bog

\section{Evanđelje po Ivanu, Proslov}

U Starom zavjetu (Knjiga Postanka) stoji :

"I reče Jahve, Bog: "Nije dobro da čovjek bude sam... "Tada Jahve, Bog načini od zemlje sve životinje u polju i sve ptice u zraku, $i$ privede ih čovjeku da vidi kako će koju nazvati, pa kako koje stvorenje čovjek prozove, da mu tako bude ime. Čovjek nadjene ime svoj stoci, svim pticama u zraku $i$ životinjama u polju". ${ }^{34}$

U Kur'anu, svetoj knjizi svih muslimana stoji :"I pouči On Adema nazivima svih stvari, a onda ih predoči melekima $i$ reče:"Kažite Mi nazive njihove ako istinu govorite". "Hvaljen nek si !" rekoše oni -"mi znamo samo ono čemu si nas Ti poučio ...."O Ademe", - reče On kaži im ti nazive njihove"! I kad im on kaza njihove nazive, Allah reče...."

\footnotetext{
${ }^{34}$ Biblija, Knjiga Postanka, Stvaranje svijeta 18, 19, 20, 21

${ }^{35}$ Kur'an, Krava-Al-Baqara 31,
} 
Potvrde o božanskom porijeklu jezika nalazimo i u najstarijim svetim indijskim tekstovima, npr. u $\operatorname{Rg}$-Vedi $(8,100,11)$ se kaže: "Božansku riječ (ili božicu Riječi) stvorili su bogovi". ${ }^{36}$ Prema svetoj knjizi Popol Vuh Quiche'-indijanaca iz Gvatemale svijet je stvorila Božija riječ, a prema staroegipatskoj mitologiji svijet je stvorio bog Atum svojom božanskom riječi. Sama interesovanja za jezičke probleme, koja se javljaju još od najstarijih vremena ljudskog postojanja, mogu se upravo povezati sa interesovanjima za jezik kulta i magije i to onaj jezik koji je ostao sačuvan u raznim svetim spisima $\mathrm{i}$ tekstovima. Uzmimo za primjer samo detaljne opise jezika Veda koji su nastali još u najstarijim danima hindu religije. Stari Arabljani su osnovali prave gramatičke centre, a sve s ciljem proučavanja, očuvanja i pravilnog čitanja jezika Kur'ana. Dakle, sam motiv za proučavanje jezika u arapskom svijetu bio je upravo jezik Kur'ana, muslimanske svete knjige. Tradicija je nalagala da se taj sveti jezik dat od Boga ne smije ni u čemu mijenjati, pa tako ni prevoditi. Slično starim Arapima, Hebreji su preuzevši njihove metode radili iscrpne filološke analize jezika Starog zavjeta (hebrejskog jezika). Tradicija izučavanja latinskog jezika, kao jezika crkve, je dugo vremena bila dominantna u hrišćanskom svijetu.

\section{LEKSIČKA DISTINKCIJA JEZIKA RELIGIJSKOG STILA U ODNOSU NA KOLOKVIJALNI STIL}

Posmatranje jezika kao božanske datosti dovelo je do toga da većina religija kao svoj primarni zadatak navodi očuvanje izvornih jezika svetih knjiga i tekstova. Upravo zbog toga, možemo tvrditi da je najveća distinkcija između kolokvijalnog jezika i jezika religijskog stila i ujedno možemo na vrlo jednostavan način opravdati takvu tvrdnju samim procesom bogosluženja u većini vjerskih zajednica. U većini religija proces bogosluženja se obavlja na nekom posebnom jeziku, koji je razumljiv samo užem krugu učesnika u tom bogosluženju, obično samo svećenstvu. Kao primjere možemo navesti upotrebe latinskog jezika u katoličkom bogosluženju i upotrebu crkvenoslavenskog jezika u pravoslavnom bogosluženju. Dakle, ovdje imamo slučajeve upotrebe "mrtvih" jezika, koji su uglavnom poznati

\footnotetext{
${ }^{36}$ Glovacki, Bernardi, Kovačec, Mihaljević, Halwachs, Soring, Penzinger, Schrodt, Uvod u lingvistiku, Školska knjiga, Zagreb, 2001., str., 11.
} 
samo svećenstvu, tako da se naprosto moramo zapitati kakva je funkcija ovolike distinkcije od kolokvijalnog, vjernicima poznatog jezika. Ako pri tome imamo u vidu postulat, da je osnovna svrha poruke, koju neki pošiljalac emituje recipijentima, da ona prenese neku informaciju, a da bi došlo do prenošenja informacije poruka mora biti na jeziku koji je razumljiv i emiseru i recipijentu, jer $\mathrm{u}$ suprotnom se poruka gubi u komunikacijskom kanalu i svakako neće isprovocirati odgovor, mi se moramo zapitati kakva je funkcija mantričnog ponavljanja za svećenikom, ako vjernici uopće ne razumiju samu poruku koju im svećenik emituje. Može se zaključiti da je osnovna funkcija upotrebe, starih "mrtvih" jezika, magijska funkcija. Kako bismo to mogli objasniti ? Ako se poruka odašilje na jeziku koji je nepoznat recipijentima, analogno je da se na poslanu poruku i ne očekuje neki smišljeni odgovor, ali se očekuje povratna poruka, poruka koja upravo i ne zahtijeva odgovor, jer je isprovocirana dogmatsko-teološkim datostima. Očekuje se povratna poruka koja se može definirati kao klonirana i reemitirana poslana poruka. U takvoj poruci nema onog Descartesovog "cogito, ergo summ", jer je i sama sumnja grijeh. Ako bismo dopustili da nas zavede površnost, mogli bismo zaključiti da se sva komunikacija u trouglu Bog, svećenik, čovjek svodi na reemitiranje Božijih poruka, ali ako malo pomnije posmatramo taj komunikacijski trougao, naprosto moramo uočiti i jednu "nadjezičku" komunikaciju koju upravo izgrađuje već spomenuto mantranje-ta magijska funkcija riječi. Takva magijska funkcija jezika, kroz omamljivu ritmičnost, podrazumijeva potpuno oneobičavanje ustaljene komunikacije, što djeluje na stvaranje katarzičnog ushićenja kod recipijenata porukevjernika.

$\mathrm{U}$ islamu imamo jednu veliku razliku u odnosu na ostale dvije pomenute monoteističke religije, a to je upotreba arapskog jezika u bogosluženju, ali moramo imati u vidu da jezik Kur'ana i islamske religije nije klasični, kolokvijalni arapski jezik, već je to jezik prepun arhaizama, jezik izvornog dijalekta plemena Kurejš, tako da on u odnosu na kolokvijalni arapski jezik ima veliki otklon, pa i među pripadnicima arapskog govornog područja igra magijsku ulogu, koja bi se mogla dovesti u ravan sa ulogama latinskog i staroslavenskog jezika u katoličkim i pravoslavnim bogosluženjima. Upravo zbog ove magijske funkcije jezika unutar religijskog stila, te teoreme o 
božanskoj datosti jezika, većina religijskih zajednica insistira na očuvanju izvornih jezika. Zbog toga se i samim postupcima prevođenja svetih knjiga pristupa sa velikom pažnjom, a kod nekih religija je utvrđeno mišljenje da se postupkom prevođenja gubi na samom izvornom božanskom značenju, jer ni jedan jezik ne može zamijeniti savršenstvo Božijih riječi i sam pokušaj zamjene bi po ovakvom mišljenju predstavljao narušavanje Božijih riječi. Tako nam je poznata ogorčena borba katoličke crkve protiv protestantskih reformi, koje su između ostalog podrazumijevale i uvođenje bogosluženje na narodnom jeziku.

Unutar samog bogosluženja, propovijedi i vazovi predstavljaju jedan specifikum, jer su one na "narodnom" jeziku, a ako imamo u vidu da predstavljaju središnji dio službe, na neki način možemo konstatovati da je ovakva izmjena- nerazumljivi jezik-razumljivi jezik-nerazumljivi jezik, ustvari vješto konstruirano tlo za posebnu recepciju poruke. Upravo zbog navedenih činjenica Davy Crystal, poznata anglosaksonska lingvistica, kaže da je:"...vrsta jezika koju neka govorna zajednica koristi za izražavanje svojih vjerskih uvjerenja u javnim prigodama obično jedan od najdistinktivnijih varijeteta koje ona posjeduje. Vrlo često ona je toliko odvojena od svakodnevne konverzacije da je gotovo nerazumljiva, osim posvećenoj manjini. ${ }^{137}$ I u samom "narodnom" jeziku, koji se koristi u religijskom funkcionalnom stilu možemo uočiti veliki otklon $u$ odnosu na kolokvijalni jezik. Na leksičkom nivou na otklon najviše utječe inherentno-ekspresivna leksika: arhaizmi, historizmi, a posebnu ulogu imaju vjerski termini, koji će varirati od religije do religije. Upravo zbog takvih karakteristika religijskog jezika, uz svete knjige se često daju različite napomene, komentari i tumačenja -metatekstualni dijalog sa izvornikom.

Sama sfera upotrebe religijskog stila dovela je do toga, da riječ Bog predstavlja centralnu riječ iz koje proizlaze svi vjerski termini. Tako se riječ Bog često zamjenjuje različitim perifrazama i epitetima za Boga, a oni ujedno predstavljaju vjerske termine (Allahovog poslanika Muhammeda (a.s.), Bog-raspet na križu, jednorođeni Sin...). $\mathrm{U}$ analiziranim propovijedima to je pokazano na mnogobrojnim primjerima, te je ukazano na vrlo frekventno ponavljanje imena Bog,

\footnotetext{
${ }^{37}$ M.Katnić-Bakaršić, Stilistika, Ljiljan, Sarajevo, 2001., str.70.
} 
različitih fraza i perifraza za Boga, a sve radi iskorištavanja njihove apelativne funkcije na vjernike. Epiteti, u religijskom stilu, predstavljaju vrlo zanimljivu leksičku grupu, jer se mogu izdvojiti oni epiteti koji postaju klišeizirani za određene religije, tako da njihova upotreba jednostavno postaje nužna (alejhisselam, sveti, dželešanuh...) i da ih slobodno možemo nazvati ustaljenim, "obaveznim" vjerskim epitetima.

Kada govorimo o arhaizmima, na tekstovima navedenih propovijedi smo pokazali da oni $\mathrm{u}$ oratorskom vidu nisu zastupljeni $\mathrm{u}$ velikoj mjeri, ali zato je njihova frekvencija vrlo velika pri korištenju obaveznih citata iz svetih knjiga. Pa tako možemo zaključiti da svete knjige i tekstovi obiluju arhaizmima, te da njihovo dosljedno intertekstualno umetanje u propovijedi također predstavlja jedan veliki otklon od kolokvijalnog jezika. Pored otklona od kolokvijalnog jezika, umetanje citata iz svetih knjiga, tekstovima propovijedi daje i jedan neosporivi imperativ, čija je osnovna funkcija persuasivna, a iz koje proizlaze apelativna i ekspresivna funkcija, o čemu je bilo govora $\mathrm{u}$ tekstostilističkoj analizi. Leksička distinkcija religijskog jezika u odnosu na kolokvijalni nije samo u vjerskim terminima i arhaizmima, nego možemo uočiti i frekventnost eufemizama. O tome R. Hadžiefendić-Parić kaže: "Različitost upotrebe jezika u vjerskom stilu u odnosu na kolokvijalni očigledna je već kod imenovanja nekih ljudskih osobina: "ljubitelj žena" (što je eufimizam razgovornog jezika) u crkvi je "preljubnik", nemoralno djelo u vjeri je "grijeh", nemoralna osoba je "grješnik". ${ }^{38}$

\section{KLIŠEIZIRANI UVOD I ZAVRŠETAK (ŠEMATIZIRANOST)}

U analizi priloženih tekstova smo mogli uočiti da svaka propovijed ima klišerizirani uvod i kraj. To se najbolje može vidjeti u tekstostilističkoj analizi, gdje smo izdvojili klišeizirau inkoativnu (kataforičku) i finitivnu (anaforičku) rečenicu, koje su uvijek istog tipa u tekstovima, koji pripadaju islamskom i pravoslavnom vjerskom krugu.

${ }^{38}$ R. Hadžiefendić-Parić, Naš jezik, Sarajevo Publishing, Sarajevo, 2003., str. 48. 
Inkoativne rečenice uvijek podrazumijevaju invokaciju (zazivanje Božijeg imena). Na primjer:

Hvala Allahu, Stvoritelju svjetova, na milosti i nimetima kojima nas daruje.

Kod katoličkih tekstova invokacija se izostavlja, ali kao klišeiriziranu, prvu (inkoativnu) rečenicu imamo eksklamaciju tipa Draga braćo i sestre!, koja se takođe uvijek javlja i kod islamskih i kod pravoslavnih tekstova, ali tek nakon invokacije. Za razliku od invokacije koja je specifična za religijski stil, eksklamacija tipa Draga braćo i sestre! podrazumijeva obraćanje kao signal za početak govora i ona se javlja u sličnim vidovima u oratorskom stilu, osim što distinkciju čini ono svojatačko "braćo i sestre", o čemu je bilo više govora u tekstostilističkoj analizi. Finitivna rečenica je kod svih tekstova uvijek istog tipa-Amen/Amin! Inkoativna i finitivna rečenice navedene tekstove propovijedi, kao što okvir uokviruje neku sliku, te upravo, na osnovu tog "okvira", mi možemo prepoznati ustaljene modele unutar njega.

\section{PERSUASIVNA (UBJEĐIVAČKA) FUNKCIJA RELIGIJSKIH TEKSTOVA (VISOK STEPEN ZADATOSTI)}

Od svih vrsta religijskih tekstova, propovijedi/vazovi imaju najizraženiju persuasivnu (ubjeđivačku) funkciju. Primarnost ove funkcije je imperativ i kod oratorskog stila, i tu možemo povući jednu paralelu, jer propovijedi/vazovi de facto spadaju u vjerske govore. Iz persuasivne funkcije proizlazi i ideološka funkcija, jer je primarni zadatak propovjednika/hatiba da vjernike uvjeri $u$ istinitost svojih tvrdnji. Da persuasivnost, $u$ tekstovima propovijedi i vazova, ne bi bila kruto imperativno provedena, realizira se kroz fatičku i emotivnu funkciju i upravo zbog tako visokog stepena zadatosti (upoućivanja poruke na samu sebe) ovi tekstovi imaju visoko formalizirane forme. Dakle, osnovna funkcija poruke u tekstovima navedenih propovijedi nije informativna, nego nasuprot tome, ona je usmjerena ka tome da se jedna grupu ljudi-vjernika u određenoj sociokulturnoj zajednici, prepozna kao jedinstvena (braća i sestre po vjeri). Propovijedi/vazovi su upravo zbog ovakve konativne funkcije uvijek u monološkoj formi, koja obavezno u sebe uključuje: retorička pitanja, obraćanja i 
eksklamacije, upotrebu prvog lica množine, imperativ i citate iz svetih knjiga.

\section{KONSTRUKCIJA TEKSTOVA}

Posebno zanimljivo pitanje u konstrukciji religijskih tekstova svakako su stilistički tekstualni konektori. U ulozi stilističkih tekstualnih konektora u tekstovima propovijedi, kako je to već pokazano u analizi korpusa tekstova, javljaju se: različite figure ponavljanja (anafora, epifora, anadiploza, polisident i paralelizmi).

Međutim od svih nabrojanih figura ponavljanja, pri konstrukciji teksta, najznačajniju ulogu ima anafora i njena upotreba pri slaganju tekstova propovijedi je najfrekventnija. Na primjer:

Dužnost je svakog muslimana i muslimanke tražiti znanje na svakom mjestu, pa gdje god se nađe. Dužnost je svakog Bošnjaka da se bogati znanjem da bi nam svima vjera bila što jača, mir što sigurniji i sloboda što tvrđa.

Sve figure ponavljanja imaju značajnu ulogu pri rekurencijipovezivanje teksta putem različitih ponavljanja jezičkih jedinica. Osim anafore kao različito frekventni stilistički konektori javljaju se: gradacija, retorička pitanja, obraćanja i eksklamacije. Pored stilističkih konektora, koje posmatramo na nivou tekstostilistike, kao posebno zanimljive konstitucione elemente teksta, na nivou sintaksostilističke analize, možemo izdvojiti sintaksičke figure dodavanja (kumulaciju, sinatrezam i distribuciju) i figure permutacije (inverziju i paralelizam).

\section{ZASTUPLJENOST STILSKIH FIGURA}

Prije generalnog zaključka o frekventnosti pojedinih figura u navedenim tekstovima propovijedi/vazova, najprije trebamo imati u vidu sam specifikum tih tekstova, koji intertekstualno uključeni u ostale diskurse bogosluženja sami po sebi predstavljaju jedan konekcioni dodir sa Bogom. Ako pođemo od ovakve tačke gledišta, automatski sve figure moramo posmatrati, različito nego figure u svim ostalim nereligioznim tekstovima, jer ni u jednom drugom stilu figure iza sebe nemaju taj nedodirljivi božanski autoritet. 
To je lijepo ilustrovao V. Fererski: "Kad propovjednik propovijeda riječ Božiju ne vodeći brigu o pjesnicima..., niti mameći sluh zvučnim frazama, nego propovijeda samo riječ od Boga objavljenu, u tom slučaju ne propovijeda on, nego Duh Sveti govori u njemu ili sam Krist..., a propovjednik je samo običan instrument koji svira. Kao što kad muzičar svira na jednom instrumentu ne kažemo da je to melodija instrumenta, nego onoga ko na njemu svira, tako je $i$ kod dobrog propovjednika ... Zato i mi zahvaljujemo Bogu bez prestanka što ste, primajući riječ Božiju, to jest našu propovijed, primili je ne kao riječ ljudsku, nego kao što uistinu jest riječ Božija. ${ }^{1{ }^{\prime 39}} \mathrm{Na}$ osnovu ovakve tačke gledišta možemo na vrlo zanimljiv način posmatrati alegorije i metafore u religijskom stilu. Ove figure uvijek prikazuju Boga ili neki od božanskih aspekata. U analizi tekstova već smo ukazali na svu ljepotu alegoričnosti samo jedne riječi, samog naziva jedne propovijedi-Tijelovo. O značaju metafore u islamskom religijskom stilu pisao je još Ahmed Sin Hasanov Bošnjak (kometarušući al-Samarqandijev traktat o metafori), prijevod njegovog djela nam donosi E. Duraković. U arapskoj terminologiji metafora se označava terminom al- mağga $z$, ali pod tim pojmom u općenitom smislu se označava preneseno značenje, tako da sam pojam podrazumijeva u sebi metaforu, ali je njegovo značenje i dosta šire i obuhvata i ostale figure "koje prenose značenje". Ovdje bismo mogli povući paralelu sa zapadnoevropskim shvatanjem metafore po kojoj ustvari imamo samo jedan trop- metaforu, iz koje proizlaze svi ostali tropi. Kao zanimljiv primjer metafore $\mathrm{u}$ islamu, možemo uzeti Durakovićevo tumačenje metafore riječi džennet. Sama riječ džennet u arapskom svijetu ima veoma iznijansirana značenja (arap. ̆̆nn, pokrivanje, skrivanje, al-ğanān, srce, skriveno u grudima, al-ğanīn, embrion, skrivenu utrobi majke, Al-ك̆anna(t), gusti vrt, koji je pun drveća, vinove loze i palmi, koji skriva svojom hladovinom).

Nakon obrazlaganja iznijansiranog značenja korijena riječi džennet, Duraković kaže: Dakle, ovdje imamo, kao u svakoj poredbenoj metafori dva korelata: ono što se poredi (Raj) i ono s čim se poredi (vrt), ono što pozajmljuje ime i ono čije se ime pozajmljuje. Drugim riječima, neko buduće iskustvo, sada potpuno nepoznato u svojoj onostranosti, a koje se želi predstaviti kao najveći mogući

${ }^{39}$ R. Hadžiefendić-Parić, Naš jezik, Sarajevo Publishing, Sarajevo, 2003., str. 48. 
užitak, predstavlja se izuzetno gustim vrtom i spasonosnom njegovom hladovinom. ${ }^{\prime 40}$ Dakle, metafore u religijskom stilu značenjski nadilaze metafore $\mathrm{u}$ ostalim stilovima, jer religijske metafore uvijek podrazumijevaju, ono onostrano, onu čovjekovu težnju za stapanjem sa Božijim bićem. Takve metafore iskorištene $u$ tekstovima hutbi/vazova, dolaze iza mantrične molitve, tako da je njihovo djelovanje na svijest recipijenata - vjernika, daleko nadišlo djelovanje obične, nereligijske metafore, jer se one u svijesti receptora poruke manifestuju kao spoj sa "Stvoriteljem". U tekstovima analiziranih propovijedi/vazova možemo uočiti i frekventnost personifikacije. Zanimljivo je da personifikacija uglavnom obuhvata riječi tipa savjest, ljubav, svjetlo, mir, dobročinstvo, dakle pojmove koje možemo okarakterisati kao "pozitivne", ali se često njima suprotstavljaju personificirani antonimi, pa dobivamo vrlo zanimljive kontradiktorne rečenice.

Na primjer:

Vjerovati znači znati da Ademova, alejhisselam, istina pobijedila Iblisovu laž; da je Ibrahimovo, alejhisselam, pravovjerje nadvladalo Nemrudovo krivovjerje...

Ostale figure (hiperbola, litota, metonimija, antonomazija, idr.), koje se javljaju $\mathrm{u}$ analiziranim tekstovima su nešto manje frekventnosti, ali su zastupljene u svim tekstovima. Između ovih figura, kao o naročito zanimljivoj, možemo govoriti o antonomaziji, za koju bi se moglo reći da u tekstovima, posebno katoličkim ima unaprijed zadane šablone (jednorođeni Sin, Bog- raspet na kirižu, dobri Pastir, betlehemsko Dijete idr.), koji se učestalo ponavljaju.

\section{UMJETNIČKA VRIJEDNOST RELIGIJSKOG STILA}

Svete knjige i tekstovi imaju ogroman značaj za samo širenje i razvoj pismenosti. O tome D. Crystal kaže: "Značaj svetih knjiga kao što su Biblija ili Kur'an za razvoj pismenosti kod mnogih naroda nesumnjiv je. Tako da se može ustvrditi da distribucija sistema pisama u svijetu danas odražava mnogo više distribuciju religija u svijetu

\footnotetext{
40 E. Duraković, Kur'anska metafora dženneta, Takvim za 1420/21.h.g., Rijaset islamske zajednice u Bosni i Hercegovini, Sarajevo, 2000., str. 12.
} 
nego distribucija jezičnih familija. ${ }^{\text {Al }}$ Neosporan je ogroman utjecaj svetih knjiga i tekstova na svjetsku književnost, ali i sam njen razvoj. Kur'an i Bibliju možemo posmatrati i sa književno-umjetničke strane, iako svakako znamo da to nije bila, niti će biti njihova primarna funkcija. O umjetničkoj vrijednosti Kur'ana, u svom djelu $O$ načelima islamske misli, poznati islamski teolog, R. Hafizović kaže:"Provirimo li u tekst Kur'ana i čitamo li ga otvorenog srca, duše i uma, tada ćemo $u$ raskoši njegovih simbola, metafora, stilskih figura, slika i znakova uočiti načelo božanske ljepote i sveto/umjetničku snagu božanskog Duha koji snagom riječi tvori to što jest ars aeterna $i$ arhitectura aeterna svetog teksta....On mudro vodi $i$ usmjerava tok povijesti, profilira lice svakog vremena i svakog prostora, svojim tvoračkim djelovanjem ispisuje stranice prirode, vječnom igrom svjetla $i$ sjene, crnog $i$ bijelog ognja ispisuje vječne jezičke znakove svog sopstvenog $i$ bogoduhnog jezika..... ${ }^{42}$ Dakle, Hafizović nam iznosi islamsku misao, koja o samom činu božanske objave govori kao o umjetničkom činu, daru božanskog jezika i mudrosti koji otkrivaju svu ljepotu svjetova. J. Kaštelan, u svom predgovoru Bibliji kaže: Za svakog čovjeka Biblija je istovremeno zbirka povijesnih isprava i književno djelo izvorne i neprolazne umjetničke vrijednosti... Po postanku i jeziku, po sadržaju $i$ stilu, po slikovitosti $i$ metaforici... ${ }^{\text {"43 }}$ Utjecaj Kur'ana i Biblije na svjetsku književnost može se proučavati u stilistici teksta, u okviru metatekstualnosti. Bezbroj je književnih djela, koja to pokazuju (M. Selimović, Derviš i smrt, H. Hesse, Demijan, N. Ibrišimović, Ahasver, M. Bulgakov, Majstor i Margarita itd.).

\section{c) UPOREĐIVANJE STILOVA}

U analizi korpusa tekstova korišteni su katolički, pravoslavni i islamski tekstovi propovijedi/vazova, a sve s ciljem da se na tekstovima različitih religija ukaže na njihove velike sličnosti, te da se na osnovu tih sličnosti daju generalni zaključci o osobinama religijskog funkcionalnog stila. Pored toga što svi ovi tekstovi zajedno spadaju u religijski stil, unutar te šire determinacije, mogli bismo izdvojiti svaki religijski tekst posebno, zavisno od toga kojoj religiji

\footnotetext{
${ }^{41}$ M. Katnić-Bakaršić, Stilistika, Ljiljan, Sarajevo, 2001., str.72.

${ }^{42}$ R. Hafizović, O načelima islamske misli, Bemust, Zenica, 1996., str. 137.

${ }^{43}$ J. Kaštelan, Uvodna riječ, Biblija, Kršćanska sadašnjost, Zagreb, 1995., str. 5.
} 
pripada, pa bismo mogli govoriti o tekstovima katoličkog religijskog stila,pravoslavnog religijskog stila i islamskog religijskog stila. Svaki od ovih stilova ima konkretne osobine na osnovu kojih se može odvojiti kao zaseban, a za sve zajedno kažemo općenito - da spadaju u religijski stil. Osnovna razlika, koju već na prvi pogled, možemo uočiti je razlika u leksici (Isus Krist/Isus Hristos/ Isa alejhisselam, Jahve/Allah, Božić/Bajram, crkva/džamija, krst/križ itd.). Ako uzmemo samo par rečenica iz dvije Biblije i Kur'ana, razlika u leksici će postati očigledna.

A ti, o Ademe, $i$ žena tvoja u džennetu stanujte $i$ odakle god hoćete jedite, samo se ovom drvetu ne približujte... ${ }^{44}$

Jahve, Bog, uzme čovjeka i postavi ga u edenski vrt...zapovijedi čovjeku: "Sa svakog stabla u vrtu slobodno jedi, ali da sa stabla spoznaje dobra i zla nisi jeo"! ${ }^{45}$

I nasadi Gospod Bog vrt u Edemu na istoku $i$ ondje namjesti čovjeka... ${ }^{46}$

U tekstovima propovijedi/vazova možemo uočiti da je kod islamskih i pravoslavnih tekstova obavezna invokacija, a da se kod katoličkih ona izostavlja. Ono po čemu se islamska i pravoslavna invokacija razlikuju je to što islamska invokacija pored zazivanja Božijeg imena podrazumijeva i salavat Božijeg poslanika Muhameda as. Međutim, i pored ovih razlika možemo zaključiti da su svi tekstovi (katolički, islamski i pravoslavni) konstruisani po tačno određenim formularima, koji sadržavaju zajedničke osobine.

\section{ZAKLJUČAK O RELIGIJSKOM FUNKCIONALNOM STILU}

Na osnovu svih specifičnih i tačno određenih osobina religijskog stila, koje je pokazala lingvostilistička analiza korpusa tekstova, na kraju ovog rada, možemo slobodno tvrditi da ne postoji niti jedna činjenica, koja bi išla u prilog tome da se religijski stil ne izdvaja kao samostalan funkcionalan stil.

\footnotetext{
${ }^{44}$ Kur'an, Sura VII, Bedemi-Al-A'raf 19.

${ }^{45}$ Biblija, Knjiga Postanka, Stvaranje svijeta 15, 16

${ }^{46}$ Biblija, Prva knjiga Mojsijeva 9
} 
Korištenjem tekstova propovijedi/vazova, induktivnim putem, ukazano je na činjenicu, da bez obzira u koju religiju tekstovi spadali, ipak zadržavaju osnovne osobine religijskog stila, te pokazuju velike sličnosti.

Neke od najkarakterističnijih osobina, koje pokazuju analizirani tekstovi su sljedeće:

1. vjerski termini, frazemi,arhaizmi (oneobičavanje leksike)

2. antonimija

3. frekventna upotreba prvog lica množine (nos modestiae)

4. imperativ

5. različiti pralelizmi-konstruktivni princip teksta

6. anafora, epifora, polisident...

7. inverzija

8. specifične metafore, alegorije, metonimije...

9. persuasivna funkcija (iz koje proizlaze apelativna i ekspresivna funkcija)

10. visok stepen zadatosti

11. ritmiziranost teksta

12. formalizirana struktura

13. invokacija

14. identične inkoativne i finitivne rečenice

Dakle, samo na osnovu ovih najkarakterističnijih osobina, koje se javljaju u analiziranim tekstovima, možemo zaključiti, da je u funkcionalnoj diferencijaciji jezika neizbježno izdvajanje religijskog stila, kao samostalnog funkcionalnog stila.

\section{Literatura:}

1. Antoš, Antica: Osnove lingvističke stilistike, Školska knjiga, Zagreb, 1974.

2. Aristotel: Retorika, Plato, Beograd, 2000.

3. Bart, Rolan: Književnost mitologija semiologija, Nolit, Beograd, 1979. 
4. Biblija, Kršćanska sadašnjost, Zagreb, 2003.

5. Borhes, Jorge Luis: Metafora, Sabrana djela, Grafički zavod Hrvatske, Zagreb, 1985.

6. Bugarski, Ranko: Jezici, Čigoja, Beograd, 1997.

7. Bugarski, Ranko: Uvod u opštu lingvistiku, Čigoja, Beograd, 1996.

8. Cerić, Mustafa: Bajramska hutba-poruka, Rijaset islamske zajednice, Sarajevo, 1996.

9. Duraković, Esad: Arapska stilistika u Bosni, Ahmed sin Hasanov Bošnjak o metafori, Orijentalni institut u Sarajevu, Sarajevo, 2000.

10. Duraković, Esad: Kur'anska metafora dženneta, Takvim za 2000. (1420/1421 h.g.)

11. Duraković, Esad: Ogled o Časnome, Takvim za 1999. (1419/20 h.g.)

12. Duraković, Esad: Prilog stilističkoj analizi el-Fatihe, Takvim za 1998. (1418/1419)

13. Duraković, Esad: Stilske vrednote poglavlja Al-Rahman, Takvim za 2000. (1420/21 h.g.)

14. Fuko, Mišel: Riječi i stvari, Nolit, Beograd, 1971.

15. Grupa autora, Glovacki, Bernardi, Kovačec, Mihaljević, Halwachs, Soring, Penzinger, Schrodt: Uvod u lingvistiku, Školska knjiga, Zagreb, 2001.

16. Hadžiefendić-Parić, Remzija: Naš jezik, Sarajevo Publishing, Sarajevo, 2003.

17. Hafizović, Rešid: O načelima islamske vjere, Bemust, Zenica, 1996.

18. Handžić, Mehmed: O hutbi, Eseji rasprave članci, Ogledalo, Sarajevo, 1999.

19. Ivić, Milka: Pravci u lingvistici, Državna založba Slovenije, Ljubljana, 1970.

20. Jakobson, Roman: Lingvistika i poetika, Nolit, Beograd, 1966.

21. Katnić-Bakaršić, Marina: Stilistika, Ljiljan, Sarajevo, 2001.

22. Kovačević, Miloš: Gramatika i stilistika stilskih figura, Drugari, Sarajevo,1991.

23. Kur'an: Prevod, Besim korkut, Medina Munevvera, 1996

24. Kvintilijan, Marko Fabije: Obrazovanje govornika, Veselin Masleša, Sarajevo, 1985.

25. Misna knjiga za narod: Krišćanska sadašnjost, Zagreb, 1981.

26. Muftić, Teufik: Klasična arapska stilistika, El Kalem, 1995.

27. Muratagić-Tuna, Hasnija: Nešto o naučnom funkcionalnom stilu, Časopis "Književni jezik" 
28. Pranjić, Krunoslav: Jezikom i stilom kroza književnost, Školska knjiga, Zagreb, 1991.

29. Radovanović, Milorad: Sociolingvistika, Novi Sad, 1976.

30. Sirovec, Ivan: Kratke propovijedi, Karitativni fond UPT, Đakovo, 2000.

31. Solar, Milivoj: Teorija književnosti, Školska knjiga, Zagreb, 1987.

32. Tošović, Branko: Funkcionalni stilovi, Institut für Slawistik der Karl-FranzensUniversität Graz, Grac, 2002. 
AMRA KOZLICA, M.A.

RELIGIOUS STYLE (FUNCTIONAL STYLE ANALYSIS)

\section{SUMMARY}

Research goals of this work manifest itself in an attempt to support the thesis that religious style represents a separate functional style with its specific qualities and functions. Religious rhetoric groups are precisely selected from all other religious genres and groups, because they have the biggest deviations compared to predetermined religious style patterns, and provide the most expression liberty in individual style pronunciation. This work attempted to claim that hutbas/lectures and homilies still contain and express the most specific religious style qualities, despite the individual style influence and a loss of certain specific religious style qualities. This fact justifies this styles separation as a separate functional style.

Key words: style, discourse, register, social linguistics, functional language differentiation, functional stylistics, religious functional style, textual stylistics, strong language positions, hutbas lectures - homilies, Divine specific language conditions, lexis, persuasion, art value 


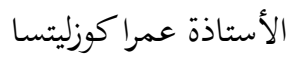

\section{الأسلوب الديني (تحليل الأسلوب الفعال)}

\section{خلاصة البحث}

بناء على تحليل النصوص والخطب والمواعظ والنصائح الدينية، تتجلى أهداف ومهام هذا البحث في الرغبة أن ندعم الفرضية أن الأسلوب الديني أسلوب فعال خاص بصفاته ووظائفه

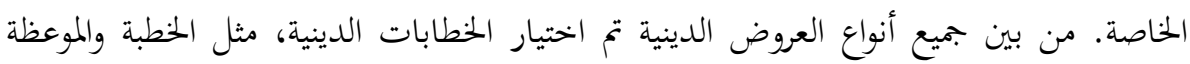
والنصائح الدينية لأفا تخرج من قوالب الخطابات الدينية وتعطي للخطيب أكبر قدر من الحريات عند التعبير عن أسلوبه الشخصي. في الواقع، بعد أخذ هذا النوع الأكثر حريةً من بين الأساليب الدينية، حاولنا أن نشير إلى الى

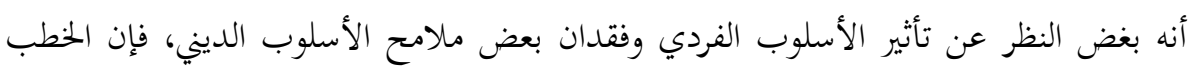

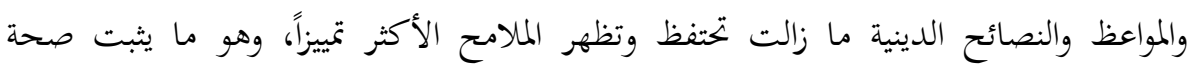
تخصيص هذا الأسلوب كأسلوب مستقل فعال.

الكلمات الرئيسة: الأسلوب، الخطاب، السجل، علم اللغة الاجتماعي، التمايز الوظيفي

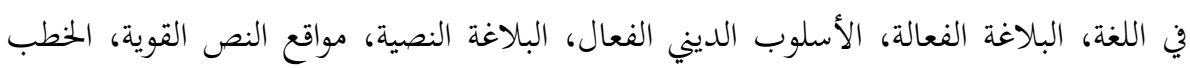
والمواعظ والنصائح الدينية، المصدر الإلهي للغة، المعجم، القيمة الفنية. 